Pamiętnik Literacki 2016, 3, s. 93-117
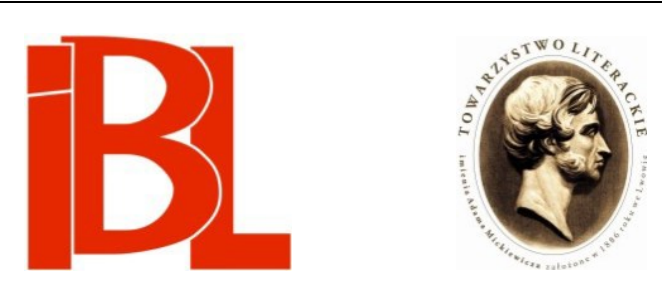

\title{
Wobec ocalałych i ich opowieści. Elementy warsztatu reporterskiego Hanny Krall
}

Anna Tatar 


\section{WOBEC OCALAEYCH I ICH OPOWIEŚCI ELEMENTY WARSZTATU REPORTERSKIEGO HANNY KRALL}

W wywiadach prasowych na pytania o formułę własnego pisarstwa Hanna Krall konsekwentnie odpowiada, że jest reporterką ${ }^{1}$. Od momentu rozmowy z Markiem Edelmanem i książki Zdażyć przed Panem Bogiem (1977) skupiła się na przedstawianiu zagłady Żydów, a także ich przedwojennego życia w Polsce i losów osób ocalałych po wojnie. To powiązanie dwóch fundamentalnych właściwości pisarstwa Krall ma zasadnicze znaczenie dla prób scharakteryzowania jej warsztatu oraz zrozumienia koncepcji tej twórczości. Zarówno bowiem reportaż (szeroko pojmowany: jako gatunek literacki, metoda pracy, a nawet realizacja pewnej etyki), jak i tematyka Zagłady ${ }^{2}$ stawiaja przed autorką określone wymagania i ograniczenia. Nie tylko sprostanie im, ale przede wszystkim ich przekroczenie i wejście w obręb wielkiej literatury przesądzają o specyfice pisarstwa Krall.

W przypadku tekstów tej autorki zamiar precyzyjnego wskazania ich przynależności gatunkowej napotyka różnorakie trudności. Po pierwsze, według Krzysztofa Kąkolewskiego:

1 Zob. G. Korzeniows ka, Reportażu wyuczam. Rozmowa z H. Krall. „Przemiany” 1989, nr 11: „nie wybierałam dziennikarstwa, tylko reportaż. Bycie reporterem to pewna odrębna filozofia zawodu, a nawet filozofia życia. Mam taką prywatną teorię, że jedni ludzie żyją, a drudzy ludzie za-pisują. Żyją ci, którzy budują, niszczą, rządzą, walczą, a inni zapisują ich prawdziwe życie. Ja jestem ta, która zapisuje, i to jest powołanie reportera”. Zob. też E. B o n i e c ka, Ciagnie mnie do picu. Rozmowa z H. Krall. „Sukces” 1993, nr 8. - H. Kr a 11, Reporterka. Rozmowy z Hanna Krall. Wybór, kompozycja, uzupełnienia, dokumentacja J. An t c zak. Warszawa 2007. - Powieść dla Hollywood. „Gazeta Wrocławska” 2007, nr z 30 XI. Na stronie: http://wroclaw.naszemiasto.pl/ archiwum/1574094,powiesc-dla-hollywood,id,t.html (data dostępu: 25 VI 2016). - M. N a l e w s k i, „Ksiażki to trudni znajomi”. Hanna Krall dla „Newsweeka”. „Newsweek” 2011, nr 51.

2 W niektórych wywiadach prasowych (np. E. Grygie1, Z. Skrok, Opisuję świat, jaki byt i jaki jest, i nie zadaje pytań - dlaczego. Rozmowa z H. Krall. „Nowe Książki” 1993, nr 7, s. 2) reporterka dystansowała się wobec takiego charakteryzowania jej twórczości: „Nie lubię określenia "temat żydowski". To nie jest określenie właściwe. W ogóle nie piszę o "tematach". W Tańcu na cudzym weselu są nieszczęsne matki, porzucone córki, niekochane kobiety, są też ofiary i mordercy. Czy myśli Pan, że to ważne - która matka jest Żydówką, a która Niemką?” Jednak w późniejszych rozmowach autorka książki Zdażyć przed Panem Bogiem już nie odżegnuje się od tego określenia i na pytanie dziennikarzy (K. J a n ow s ka, P. M u cha r s ki, O nienormalności świata. Wywiad z H. Krall. „Tygodnik Powszechny” 2000, nr 13, s. 10): „W jaki sposób trafiła Pani na swój temat?”, odpowiada: „Zastanawiam się, kto kogo znalazł, ja - temat, czy temat mnie?” Zob. też M. C i eśli k, Grecka tragedia i różowe pióra Hanny Krall. „Newsweek” 2009, nr 20. 
Reportaż nie ma dotąd powszechnie uznanej definicji. Może to wynikać ze zmienności i ciagłego rozwoju definiowanego przedmiotu, jak i braku dyscypliny nauk, która by stworzyła aparat badawczy przystosowany do literatury faktu ${ }^{3}$.

Po drugie zaś, same dzieła Krall trudno zaliczyć do reportażu w rozumieniu klasycznym. Anna Dobiegała twierdzi:

To prawa literatury Holokaustu, której źródłem gatunkowym jest temat masowej eksterminacji sześciu milionów Żydów, wymusiły niejako na autorce Zdażyć przed Panem Bogiem przełamanie, nie rozproszenie, ale właśnie przełamanie, przekroczenie, granic gatunkowych reportażu, choć z drugiej strony w pełni pozwoliły wykorzystać jego możliwości, dotąd niezauważane i niedoceniane ${ }^{4}$.

Badacze dorobku literackiego Krall starali się wprowadzić rozmaite klasyfikacje gatunkowe jej dzieł. „Baśnie dokumentalne”, „ballady”, „opowiadania”, „opowiadania dokumentalne" (J 37-38) to tylko kilka spośród określeń przywoływanych przez Joannę Jeziorską-Haładyj ${ }^{5}$, która rekapitulowała dotychczasowe ustalenia w tej kwestii. Należałoby tu wymienić jeszcze termin „reportaż holokaustowy”, używany przez Dobiegałę w jej dysertacji doktorskiej ${ }^{6}$.

Biorac to wszystko pod uwagę, w swojej pracy pominę przeprowadzenie szczegółowej analizy przynależności genologicznej tekstów Krall (odstąpię od tej zasady jedynie w kilku miejscach, gdy będzie to niezbędne dla jasności wywodu). Z określeń proponowanych przez badaczy - za najbardziej przydatne dla moich przemyśleń uznaję „reportaż literacki”. Jeziorska-Haładyj odnajduje większość jego cech w pisarstwie reporterki:

wykracza [twórczość Krall] poza refleksje doraźne i jednostkowe, dążąc do formułowania prawd uniwersalnych; przynosi osobistą, wartościującą perspektywę opisu zjawisk; wyróżnia się szczególną, rozpoznawalną formą (przez niektórych krytyków nazywaną manierą; chodzi o takie cechy stylu, jak wielość powtórzeń na różnych poziomach organizacji tekstu: refreniczność, paralelizmy, anafory, anadiplozy, prostota składni, nagromadzenie szczegółów). Ponadto dokonywany przez Krall „faktomontaż”, czyli selekcja i kompozycja faktów, przypomina niekiedy schematy fabularne znane z powieści. [J 38]

W kontekście pisarstwa Krall ciekawe spostrzeżenia na temat reportażu literackiego (stanowiące przy tym niejako uzupełnienie przytoczonej charakterystyki, która dotyczy raczej tekstu niż jego autorki) przynosi artykuł (z 1961 roku) Jerzego Lovella:

3 K. Kąk olews ki, Reportaż. Hasło w: Stownik literatury polskiej XX wieku. Red. A. B rodzka [i in.]. Wrocław 1992, s. 931. Podobne spostrzeżenie zanotował rok wcześniej K. Wolny (O poetyce wspótczesnego reportażu polskiego 1945-1985. Rzeszów 1991, s. 33): „Dotychczas nie ustalono jednoznacznie pojęcia reportażu. Ilu twórców i teoretyków, tyle określeń, opartych na wielu różnych kryteriach". Wydaje się, że rozpoznania obu autorów dotyczące wciąż dyskutowanych i nieostatecznych cech gatunkowych reportażu pozostają aktualne.

4 A. D o bi e gała, Pamięć traumy i trauma pamięci. Zapis doświadczenia Holokaustu $w$ twórczości Hanny Krall. Gdańsk 2012 (dysertacja doktorska). Dziękuję autorce za udostępnienie elektronicznej wersji jej tekstu.

5 Skrótem J odsyłam do: J. J e zi o r s k a-H a ła dy j, Zawartość zmyślonej, żółtej walizki. O prozie Hanny Krall. „Pamiętnik Literacki” 2010, z. 4. Ponadto stosuję następujące skróty do utworów H. Kr a 11: H = Hipnoza. Warszawa 1989; T = To ty jesteś Daniel. Kraków 2001. Liczby po skrótach oznaczają numery stronic.

$6 \quad$ D o bi i g a ł a, op. cit., rozdz. Od dokumentaryzmu do literackości. 
z reportażem literackim mamy do czynienia wówczas, gdy reporter, zachowując w zasadzie ogólne rygory „klasycznego” reportażu - wkracza w obszar problemów należących do literatury. Wyraża wtedy część rzeczywistości najtrudniejszą i najbardziej złożoną. Niekiedy sztafażem prostym, językiem wziętym z dziennikarstwa, a niekiedy środkami literatury. To jest kryterium drugorzędne $\langle\ldots\rangle$.

Dalej autor precyzuje:

„wejście w obszar literatury” wiedzie przede wszystkim poprzez własna postawę wobec świata reportera. Jeśli jest obarczony szablonami, jeśli żyje w wąskim tylko kręgu spraw profesjonalnych, jeśli nie podejmuje ryzyka własnego sądu i własnej odpowiedzialności - obszar literatury jest dla niego zamknięty ${ }^{7}$.

Według Lovella o literackości reportażu decyduje zatem przybranie przez reportera postawy etycznej, którą charakteryzuje umiejętność i chęć zakwestionowania ustalonych przekonań, odwaga w docieraniu do głębi zjawisk i problemów, kierowanie się głosem sumienia w osądzaniu ukazywanych konfliktów. Sądzę, że wymienione elementy można odnaleźć w pisarstwie Krall (szczegółowo omówię to w dalszej części pracy).

Przedmiotem mojej analizy sa utwory powstałe na przestrzeni prawie 40 lat, w zmieniającej się sytuacji politycznej, społecznej i kulturalnej. Wraz z upływem czasu pisarstwo Krall - co wydaje się oczywiste - ewoluowało ${ }^{8}$. Stąd określanie jej tekstów mianem reportaży literackich (a w skrócie po prostu jako reportaży) ma charakter dalece umowny, a nawet niejako symboliczny. Ta dość ogólna kwalifikacja przede wszystkim wskazuje na wspólne im zasadnicze cechy gatunkowe (choć realizowane $\mathrm{w}$ poszczególnych utworach w różnym stopniu i w rozmaity sposób), ale nie rości sobie prawa do precyzji i definicyjnej trafności w każdym przypadku. Melchior Wańkowicz, postulując „poszerzenie konwencji reportażu”, przestrzegał przed podejmowaniem nazbyt zawłaszczających i w konsekwencji nieadekwatnych prób normatywnego opisu nowych zjawisk w literaturze. Uzasadniając swoje stanowisko, przytoczył m.in. słowa Samuela Morrisona (autora biografii Krzysztofa Kolumba oraz monumentalnej historii marynarki amerykańskiej w latach drugiej wojny światowej), „o zamieszaniu, jakie u współczesnych wywołał Moby Dick”: „ „Cóż to jest - pytano. - Powieść? Alegoria? Traktat o wielorybnictwie? Jeszcze co innego? - Wszystko to razem - konkluduje Morrison - i jeszcze co innego" 9 . Podobnie wygląda sytuacja $\mathrm{z}$ każdym $\mathrm{z}$ tekstów Krall - zdają się one mieścić w sobie zbyt wiele, by zamknąć je w jednej precyzyjnej formule, zdolnej wyczerpać całe ich artystyczne bogactwo.

Agata Tuszyńska kończy swój artykuł - złożony z wypowiedzi Krall cytowanych dosłownie bądź przytaczanych w mowie pozornie zależnej - następującym stwierdzeniem o roli reporterki: „Jest po to, żeby zapisywać. Sądzi, że skoro przeżyła, to właśnie po to" ${ }^{10}$. Próbując opowiedzieć Zagładę, reporterka, podobnie jak wielu

7 J. Love11, Notatki o reportażu. W zb.: Reportaż. Wybór tekstów z teorii gatunku. Wybór, oprac. K. W olny. Rzeszów 1992, s. 25, 26. Pierwodruk: „Życie Literackie” 1961, nry 37-38, 40.

Zob. rozdz. Kształty pamięci książce K. Mą k i - Ma laty ń s ki ej Krall i filmowcy (Poznań 2006).

9 M. W ańkowicz, O poszerzenie konwencji reportażu. W zb.: Reportaż, s. 62. Pierwodruk w: M. W a ńk ow i c z, Od Stołpców po Kair. Wyd. 3. Kraków 1977.

10 A. Tuszyń s ka, Żeby zapisywać. Spotkanie z Hanna Krall. „Więź” 1988, nr 3, s. 58. 
innych twórców, znalazła się w sytuacji paradoksalnej, określonej przez Michała Głowińskiego jako „wielkie zderzenie”:

mamy tu do czynienia z nieprzekazywalnością doświadczeń. Ale z ową niemożnością przekazywania sprzężone jest od samego początku poczucie, że przekazywanie jest obowiązkiem, od jakiego nie należy się uchylać, towarzyszy jej zatem wysiłek, podejmowany w różnych okolicznościach i w różnych postaciach, by zostawić ślad, towarzyszą próby, zmierzające ku temu, by to, co niewyrażalne, uczynić wyrażalnym ${ }^{11}$.

O swoich zmaganiach z koniecznością „zaświadczenia dziejów” 12 (przeżyć tych, którzy ocaleli, ale też przeżyć własnych ${ }^{13}$ ) Krall mówiła w wywiadach prasowych, zarazem podkreślając swą świadomość tego, iż dotychczasowe środki wyrazu są niewystarczające:

Kiedy napisałam Zdą̇yć przed Panem Bogiem i zobaczyłam, jaki może być rezonans społeczny ksiażki, jak wielu ludzi ją czyta - zrozumiałam, że strasznie ważne rzeczy można przez reportaż przekazać. I wtedy zaczął się mój niepokój: czy ja dostatecznie wykorzystuję możliwości reportażu. Ten niepokój mi towarzyszy do dziś ${ }^{14}$.

Co istotne, Krall uznaje, iż także na jej rozmówcach - ocalałych i świadkach Zagłady - ciąży powinność opowiedzenia jej, jako reporterce, o tych doświadczeniach. Przyznaje sobie prawo do poznania ich wiedzy i wspomnień, by następnie móc je opisać i udostępnić czytelnikom ${ }^{15}$.

W wywiadzie $z$ Katarzyna Janowską i Witoldem Beresiem przywołuje jedna ze swoich trudniejszych rozmów - z późniejszym bohaterem reportażu Fantom bólu ( $\mathrm{z}$ tomu Taniec na cudzym weselu). Tym razem interlokutorem Krall był major

11 M. Głowiński, Wielkie zderzenie. „Teksty Drugie” 2002, nr 3, s. 204. Zagadnienie to należy do podstawowych problemów analizowanych w pracach na temat świadectw Holokaustu. Tak np. A. H. Ro s e n feld w swojej, dziś już klasycznej, książce Podwójna śmierć. Rozważania o literaturze Holocaustu (Przeł. B. K r a w c o w i c z. Warszawa 2003, s. 22) wskazywał „na napięcie pomiędzy niemożliwością i koniecznością pisania o śmierci idei człowieka po to, by ideę tę utrzymać przy życiu”. Dość obrazowo, parafrazując fragment tekstu U nas w Auschwitzu... T. B o r o w s ki e g o, opisuje ten problem M. C i chy (Baśnie dokumentalne Hanny Krall. „Gazeta Wyborcza” 1999, nr 19, z 23 I, s. 16): „Klasyczne tragedie opowiadały o skazanej na klęskę walce człowieka z klątwą, losem, przeznaczeniem. Pomnóżmy Prometeusza, Edypa, Króla Lira albo Józefa K. przez milion, a objawi się nam paradoks Holocaustu: oto jest masowa tragedia, w której miliony zwykłych ludzi zostają postawione w sytuacji tragicznych bohaterów - pod ściana przeznaczenia. Jak jednak opowiedzieć historię miliona Hiobów? Zwłaszcza jeśli ta historia jest prawdziwa?"

Odwołuję się tu, oczywiście, do artykułu J. J e dli c k i e g o Dzieje doświadczone i dzieje zaświadczone. W zb.: Dzieło literackie jako źródło historyczne. Materiały konferencji naukowej. Warszawa, 14-16 grudnia 1976 r. Red. Z. Stefa now s ka, J. Sławiński. Warszawa 1978.

13 Tę kwestię omówię dokładniej w dalszej części pracy.

14 K. Meloch, Cytaty. „Kontrasty” 1981, nr 2, s. 38. Zob. nieco wcześniejszą wypowiedź H. Kral1 o książce Zdażyć przed Panem Bogiem (w: J. Grodzińs ki, Rzeczy najważniejsze. Rozmowa z H. Krall. „Warmia i Mazury” 1978, nr 3): „Od początku byłam onieśmielona tematem. Wymagał pokory. Zdawałam sobie sprawę, że to jest temat jedyny na świecie, niepowtarzalny. Bałam się, że go nie uniosę".

15 Zob. K. Ko n e cka, Porażona szarością. „Kontrasty” 1981, nr 2: „Udało mi się przekonać Edelmana, że jego przeżycia nie są jego prywatną sprawą, że ma nawet obowiązek opowiedzieć o tym ludziom”. 
Wehrmachtu, baron Axel von dem Bussche, który podczas wojny w miejscowości Dubno na Wołyniu widział, jak esesmani masowo rozstrzeliwali Żydów. Po tym wydarzeniu postanowił przeprowadzić zamach na Hitlera. Autorka przedstawia atmosferę panująca $\mathrm{w}$ trakcie spotkania $\mathrm{z}$ majorem (odbyło się ono w Niemczech, na zamku jego córki) i przebieg ich rozmowy:

trzeciego dnia, kiedy już wszystko gładko opowiedział, zapytałam: „Panie baronie, a z jakiej odległości patrzył Pan na tych nagich ludzi?”, bo chciałam wiedzieć, czy mógł dostrzec twarze stojących, czy zapamiętał je... Moje pytanie zniweczyło miły nastrój ${ }^{16}$.

Von dem Bussche przerwał opowieść i zażądał, by to, co już zrelacjonował, zostało opublikowane dopiero po jego śmierci. Krall pomyślała wówczas:

„Mój Boże, ja muszę wiedzieć, ja mam prawo wiedzieć, jak było w Dubnie”. I jeszcze: „Gdyby pamięć była dyskietką w mózgu, gdybym wiedziała, gdzie jest, wydarłabym ją z niego choćby siłą” ${ }^{17}$.

Jacek Leociak, analizując motywacje autorów, którzy tworzyli dokumenty Zagłady ta m i w te dy, odwołuje się do „szczególnie pojętego profetyzmu”, spełniającego się „w kategorycznym i nie znoszącym sprzeciwu nakazie pisania i świadczenia".

Autor działa w poczuciu wypełniania misji. Ma mówić w imieniu tych, którzy już mówić nie mogą. Ma przekazać prawdę, którą świat musi poznać ${ }^{18}$.

Wydaje się, że taki cel przyświeca również Krall. Reporterka usiłuje wydobyć od barona ową historię, wie bowiem, iż jest on jedynym człowiekiem, który potrafi powiedzieć, co zdarzyło się w Dubnie. Samą siebie natomiast uważa za osobę wybraną, by to świadectwo utrwalić. We własnych tekstach i wywiadach wielokrotnie wspominała o Wielkim Scenarzyście, utożsamianym z Bogiem (lub z Przypadkiem, losem) ${ }^{19}$, odsłaniającym przed nią „swoje kunsztownie splątane historie” ${ }^{20}$. Krall zdolność do łączenia w reportażach losów ludzkich, odnajdowania między nimi powiązań tłumaczyła następująco: „Scenarzysta wie, że jestem wdzięcznym słuchaczem jego opowieści, i rewanżuje się za mój podziw. Opowiada wciąż nowe i nowe historie" ${ }^{21}$. Zgodnie z kategoriami używanymi przez Leociaka świadczenie o Zagła-

K. J a n ow s ka, W. B er és, Hanny Krall dowiadywanie się świata. „Kontrapunkt” 1996, nr 3, s. III. Dodatek do „Tygodnika Powszechnego” 1996, nr 17.

Ibidem.

J. Le o c ia k, Tekst wobec Zagłady. (O relacjach z getta warszawskiego). Wrocław 1997, s. 101. Zob. H 125: „Czy to możliwe, by Wielki Scenarzysta, jakim niewątpliwie jest Bóg, ułożył aż tak kiczowatą historię?”; H. Kr a 11, Żal. W: Dowody na istnienie. Poznań 1996, s. 29: „Historie, które opowiadam, zdarzyły się naprawdę. Ułożył je Wielki Scenarzysta, są dowodem na boskie istnienie”. Zob. też rozważania na temat owej postaci w utworach Krall w cytowanej już książce Mąki - Ma la tyń s ki ej (rozdz. Wielki Scenarzysta $w$ teatrze świata).

20 A. Nizi oł e k, Niech pan kocha moich bohaterów. Rozmowa z H. Krall. „Gazeta Wyborcza. Poznań” 1996, nr 267, z 16 XI, s. 4.

21 Ibidem. Zob. też K. Bi ela s, Dramaturgia uczuć. Rozmowa z H. Krall. „Magazyn” nr 24. Dodatek do „Gazety Wyborczej” 1997, nr 136, z 13 VI, s. 22: „Teraz jestem ciekawa ludzi dorosłych. Słyszę o kimś, widzę kogoś w telewizji i chcę się czegoś więcej o nim dowiedzieć. Myślę, że świat się za tę ciekawość odwzajemnia, rewanżuje. Czasem coś ułatwia, czasem podsuwa”. 
dzie, pojmowane jako moralna powinność, lecz także i swoisty dar („Autor znajduje się w sytuacji przymusowej. To nie on wybiera, ale zostaje wybrany, powołany. Nie ma ucieczki, musi podjąć misje”" ${ }^{22}$ ), pozwala określić je za pomocą formuły „pisania natchnionego”. W tym kontekście relacjonujący zmieniają się w proroków. Nie wieszcza jednak przyszłości, lecz mają przenieść w nią głos zamordowanych.

Reporterka pyta majora o twarze rozstrzeliwanych Żydów. Chce przywrócić im imiona. Opisać pojedyncze ofiary, a nie tylko tłum. W tomie To ty jesteś Daniel Krall ponownie wraca do spotkania $\mathrm{z}$ niemieckim baronem w styczniu $1991 \mathrm{w}$ Lehrensteinsfeld. Uzupełnia to, co nastapiło po ich rozmowie. O wysłuchanej relacji opowiedziała D. (takie określenie pojawia się w tekście), wydającej jej książki w Niemczech. Reporterka zapewniła D.: „Nie napiszę o baronie. Nie będzie tekstu, w którym Niemcy mają losy i twarze, a Żydzi są bezimiennym poniżonym tłumem” (T 80). Następnego dnia Krall otrzymała od niej starą książkę: „Jest po hebrajsku i w jidysz, z jednym słowem łacińskimi literami: DUBNO. Wydano ją dawno temu, daleko od Niemiec, w paruset egzemplarzach" (T 80). Znajdowały się w niej zdjęcia żydowskich mieszkańców Dubna, na których „Ludzie uczą się, pracują, tańczą, modlą się, albo zwyczajnie pozują do obiektywu” (T 80). Reporterka dotrzymała obietnicy danej swojej rozmówczyni. Dzięki podarunkowi od D. w Fantomie bólu, zawierającym relację o rozstrzelaniu, przedstawia bowiem najpierw codzienne życie Żydów w miasteczku, sięgając aż do pierwszej połowy XVIII wieku. Pisze o stosunkach z Polakami, o wielkich rabinach i kupcach, o przestrzeganiu zwyczajów charakterystycznych dla każdej pory roku i o wyrabianiu doskonałej macy, znanej w okolicy. A przede wszystkim - o konkretnych osobach, wymienianych z imienia i nazwiska bądź przez przywołanie ich przydomków. Narratorka przyjmuje perspektywę kogoś z zewnątrz, kto na podstawie dostępnych źródeł próbuje zrekonstruować przeszłe dzieje Dubna, wybierając z nich to, co pozwoli przybliżyć sylwetki zamordowanych później Żydów ${ }^{23}$. Nieco inaczej sytuacja wygląda w przypadku historii Axela von dem B., głównego bohatera reportażu. Z wyjątkiem dociekań na temat tożsamości jego pradziadka ma ona charakter raczej wspomnień niż opartej na dokumentach i opracowaniach relacji. Wypowiedzi Axela dość często przybieraja formę mowy zależnej („Wiedział, że Rosją rządzą bolszewicy. Wiedział, że są tam łagry i że Stalin jest mordercą. Słowem - wiedział, że walczą z komunizmem i że wszystko jest w porządku”) bądź cytatów („Czy pan wie co on robi z Żydami? odpowiedział pytaniem Axel von dem B. i poprawił się: co MY robimy z Żydami”"24). Przecięcie tych dwóch równolegle prowadzonych historii: Dubna i żołnierza Wehrmachtu, być może potomka miejscowego żydowskiego kupca, następuje w momencie, gdy Niemiec staje się świadkiem masowego mordu dokonanego przez esesma-

Le o ciak, loc. cit.

W partiach narracyjnych w Fantomie bólu pojawiają się wszakże fragmenty, w których przeważa punkt widzenia żydowskich mieszkańców: „Nad Ikwę chodziło się wieczorami na spacer. Latem płynęło się łodziami za miasto. Zimą wyrą̧bywano lód, który starczał aż do jesieni. Przez cały rok czerpano wodę i konnymi beczkowozami rozwożono po mieście” (H. K r all, Fantom bólu. W: Taniec na cudzym weselu. Kraków 2002, s. 72). Paradoksalnie, ta bardziej osobista perspektywa została wprowadzona dzięki zastosowaniu bezosobowych form czasowników.

Ibidem, s. 75, 83. Więcej o relacji między słowem reporterki-narratorki a słowem bohaterów w dalszej części rozważań. 
nów. Wówczas w opowieści zaczyna dominować jego perspektywa. Zdarzenia opisuje ktoś, kto znajdował się po stronie oprawców, a mówiąc precyzyjniej (i unikając w ten sposób moralnej oceny): patrzył na to samo co oni.

W tomie To ty jesteś Daniel, we fragmencie dotyczacym zbrodni, reporterka-narratorka podejmuje radykalną próbę odwrócenia tego punktu widzenia należącego do niemieckiego żołnierza. Przeglądając książkę ze zdjęciami Żydów z Dubna, pisze o nich:

Jeszcze nie wiedzą, że mają zły wygląd. Nie wiedzą, że rozbiorą się do naga i staną w długiej kolejce. Że będą zstępowali do dołu. Że świat ukaże im na pożegnanie piękny jesienny pejzaż z młodzieńcem na koniu. [T 80]

Krall próbuje uczynić ze swojej opowieści świadectwo złożone w imieniu zamordowanych. Usiłuje podążyć za ich ostatnim spojrzeniem. Początkowo rekonstruuje wydarzenia na podstawie relacji żołnierza Wehrmachtu i księgi pamiątkowej Dubno. Sefer Zikaron z fotografiami przyszłych ofiar. W Fantomie bólu powołuje się na nią kilkakrotnie ${ }^{25}$. Korzysta też z innych źródeł, na końcu tekstu podaje ich spis (zawiera on np. dokumenty, encyklopedię, dziennik, opracowania, listy i dzieło literackie). Jednak to właśnie stara książka o Dubnie, otrzymana od D. po rozmowie na temat barona i jego wspomnień, okazała się kluczowa w podjęciu pracy nad reportażem. Umożliwiła dopełnienie historii żydowskich mieszkańców, przedstawienie ich wcześniejszych indywidualnych losów. Ale z tej roli księgi Dubno. Sefer Zikaron czytelnik może zdać sobie sprawę dopiero podczas lektury tekstu w tomie To tyjesteś Daniel. Tu samo wejście w posiadanie owej księgi stało się przedmiotem opowieści, zaczątkiem nowej historii, w niewytłumaczalny sposób przeznaczonej dla reporterki: „Nazajutrz wydarza się dziwna rzecz. D. przynosi książkę. [...] Nie wiadomo, skąd wzięła się we frankfurckiej Stadtbibliothek" (T 80). Dzieje zamordowanych Żydów w Dubnie i niemieckiego żołnierza, który był świadkiem tej zbrodni, Krall przedstawiła zatem w różnych tekstach, tworzonych na przestrzeni kilku lat. Aby je uporządkować: najpierw ukazał się Fantom bólu w tomie Taniec na cudzym weselu, potem ważny wywiad z Janowską i Beresiem dla „Tygodnika Powszechnego” (reporterka mówiła w nim o przebiegu spotkania $z$ baronem i o ich trudnych relacjach), a wreszcie - szkic w tomie To ty jesteś Daniel. Wszystkie te teksty są ze sobą powiązane, wchodzą w dialog, uzupełniają się wzajemnie, ale też na kilku płaszczyznach zawierają interesujące odmienności. Krall stawia przed czytelnikiem zadanie, by $z$ tych rozmaitych fragmentów, rozrzuconych w różnych miejscach, próbować zrekonstruować całość. Dopiero taka lektura, zakładająca również poznanie okoliczności powstawania danej historii (a więc wymagająca od odbiorcy metarefleksji) umożliwia pełniejsze zrozumienie ukazanych wydarzeń. To, jaką drogą Krall dowiedziała się o mordzie w Dubnie i co było warunkiem jego opisania w reportażach, staje się niemal tak samo ważne jak zrelacjonowanie tego, co tam się stało. Każda

Zob. ibidem, s. 69: „I w TYM SAMYM ROKU, 1728, kupiec Herszel Izaak przyjechał z Dubna na Targi Lipskie. Tak napisano w historii miasta, w księdze pamiątkowej Sefer Zikaron wydanej w Tel Awiwie...”; „"[Dubno] z daleka pięknie się przedstawia, na wzgórzu otoczonym moczarami Ikwy" - napisano w starym przewodniku". 
opowieść o Zagładzie ma bowiem swoją własną historię ${ }^{26}$. Leociak, charakteryzując w cytowanej już pracy materiały zgromadzone w archiwach, stwierdzil:

Teksty sygnowane jako NN reprezentują [...] tych wszystkich, którzy w tamtym czasie pisali, a których głos nie zdołał się do nas przedostać. Mogą świadczyć, w sposób symboliczny, o tekstach podwójnie nieznanych: napisanych, ale przepadłych bez wieści, o których istnieniu nikt nie wiedział i nikt nie zaświadczył $^{27}$.

Krall udaje się dotrzeć do takiej nieznanej historii o ofiarach esesmanów w Dubnie. Jej rozmówca nigdy wcześniej nie złożył tak dokładnej relacji na temat tamtych wydarzeń:

Opowiada niezbędnymi słowami.

Nie chce pytań. Chce wydostać się z Dubna i kulturalnie iść na kolację. [T 78]

W pewnym sensie więc to reporterka ocaliła jego świadectwo. Dlatego ma prawo stawiać wysokie wymagania czytelnikom swoich reportaży i domagać się od nich szczególnej lektury - zakładającej empatię i świadomość egzystencjalnej wagi poruszanych spraw: „Bardzo bym chciała, by ludzie czytali moje opowieści. Skoro jedni wszystko przeżyli, inni mają obowiązek o tym wiedzieć" 28 .

Ryszard Kapuściński w laudacji wygłoszonej 18 III 2001 - podczas ceremonii wręczenia reporterce Nagrody Miast Partnerskich Torunia i Getyngi im. Samuela Bogumiła Lindego - powiedział:

gleba, na której rodzi się pisarstwo Hanny Krall, nie jest zamknięty świat wyobraźni fikcjopisarza, lecz sytuacja żywej interakcji między autorką a przyszłymi bohaterami jej utworów, owa rzeczywistość twórczej i skupionej wspólnoty, w której atmosferze zaczynają kiełkować i krystalizować się przyszłe obrazy i historie. Bo też ta właśnie interakcyjność towarzysząca pisarstwu Hanny Krall nadała mu szczególnej temperatury, siły i wiarygodności ${ }^{29}$.

Wydaje się zatem, że dla prób określenia warsztatu reporterskiego Krall kluczowe jest zastanowienie się nad tym - ujmując problem nieco metaforycznie czyje głosy rozlegają się w jej tekstach, jak ze sobą współbrzmią, który z nich dominuje, czyja perspektywa przeważa w opowiadanych historiach. Te pytania wywołują szereg innych kwestii, wśród nich znajdują się: autentyczność relacji a jej literackie przetworzenie (to chyba jedno $\mathrm{z}$ najczęściej poruszanych zagadnień w pracach na temat pisarstwa Krall), stosowność używanych konwencji i języka czy wreszcie prawo rozmówców do ingerowania w gotowy tekst reportażu. Pamiętając o osadzeniu tych problemów w kontekście refleksji nad sposobami pisania o Zagładzie, trzeba wziąc pod uwagę jeszcze jedno zagadnienie, mianowicie czy reporterka musi w wyższym stopniu respektować słowa uratowanego przed Zagła-

Zob. Le o cia k, op. cit., rozdz. Losy tekstów.

Ibidem, s. 39.

K. O g i old a, Mózg to jest przereklamowany organ. Rozmowa z H. Krall. „Nowa Trybuna Opolska” 2001, nr z 2 XI. Na stronie: www.nto.pl/artykuly-archiwalne/art/3948257,mozg-to-jest-przereklamowany-organ,id,t.html (data dostępu: 25 VII 2016).

R. Ka p uś cińs ki, Przeciw rozpaczy. „Gazeta Wyborcza” 2001, nr 66, z 19 III, s. 16. 
dą niż pozostałych interlokutorów? Czy rozmowa z ocalonym obliguje ją do większej powściągliwości w wyrażaniu własnych opinii bądź wręcz do wycofania autorskiego ,ja” z tekstu?

Powieść dla Hollywoodu z tomu Hipnoza ma charakter autotematyczny:

jest [...] swoistym metareportażem, reportażem o tworzeniu reportażu, opowieścią o zbieraniu i selekcji materiału, szukaniu formy; o więzi między opisującym a opisywanym i o oczekiwaniach tego ostatniego co do sposobu zrelacjonowania jego życia. $[\mathrm{J} 40]^{30}$

Niebagatelne znaczenie mają tu również czas i miejsce publikacji tekstu: otwierają one Hipnozę, pierwszy (po ukazaniu się w 1977 roku rozmów autorki z Markiem Edelmanem) zbiór reportaży o Zagładzie. Pozwala to potraktować zawartą w Powieści dla Hollywoodu refleksję nad własnym warsztatem jako swego rodzaju programowy manifest, sformułowany przez Krall w poczatkowej fazie jej pisarstwa na temat losów Żydów. W kolejnych tekstach znajdują się bowiem raczej już tylko pojedyncze uwagi, a nie zarys całościowej koncepcji tego, jak opowiadać Zagładę.

\section{Zasłużyć na opisanie}

Kąkolewski, analizując w Stowniku literatury polskiej XX wieku relacje między piszącym reportaże a jego rozmówca, stwierdza: „Bohater nie jest powołany do życia przez autora jak w beletrystyce, ale na odwrót: autor może zaistnieć dzięki zaakceptowaniu go przez bohatera”. I dodaje Kąkolewski:

w reportażu następuje rozpad pojęcia autora. Należałoby go zastąpić polem autorskim. Między tym, który zdarzenie „stworzył”, a autorem opisu zdarzenia powstaje interakcja, rodzaj spółki autorskiej ${ }^{31}$.

Wydaje się, że w tej relacji nieco bardziej uprzywilejowana pozycje zajmuje rozmówca. To on bowiem był uczestnikiem wydarzeń ${ }^{32}$ i może, jeśli zechce, podzielić się swoimi przeżyciami $z$ reporterem:

Reportażysta zależny jest nie tylko od kształtu wydarzeń, jaki w wyniku wypadkowej działań nadali mu bohaterowie, ale także od ich decyzji, czy zechcą oni o tych wydarzeniach opowiedzieć. Bohater jest więc także narratorem, czyli źródłem informacji ${ }^{33}$.

Inaczej sytuacja wygląda w przypadku pracy reporterskiej Krall. Zajmuje ona wobec swych interlokutorów postawę bardziej zobowiązująca - oczekuje od nich współpracy. W odniesieniu do jej tekstów kategoria „pola autorskiego”, użyta przez Kąkolewskiego, oznacza nie osłabienie pozycji reporterki i konieczność podporządkowania się sugestiom rozmówców w sprawie sposobu ukazywania zdarzeń, lecz

Sama Krall określiła ten reportaż w następujący sposób (B. Ma r ze c, Bóg ma słabość do walczacych. Rozmowa z H. Krall. „Rzeczpospolita” 2006, nr z 6-7 V, s. 22): „To rzecz o tym, co dzieje się między bohaterką a autorem".

31 Kąkolewski, op. cit., s. 932.

32 O „stopniu obecności” reportera przy zdarzeniach Ką kolew s ki (ibidem, s. 933) pisze: „Początkowo naoczność uważano za konieczną, znajduje się ona w dawnych definicjach reportażu. Obecnie znamy rekonstrukcje faktów od autora odległych w przestrzeni [...], ale i w czasie [...]". 
stawianie przyszłym bohaterom reportaży konkretnych wymagań. W wywiadzie prasowym z 1993 roku Krall tak opisała warunki przystapienia do pracy nad opowieścią:

- Człowiek chce mówić, a ja chcę słuchać. Oboje musimy wiedzieć, że reportaż, który zamierzam napisać, jest naszą wspólną sprawą. Że o życiu tego człowieka warto z jakichś powodów napisać i że wobec tego powinien mi pomóc.

[...] jeżeli ktoś nie chciałby ze mną rozmawiać, nie ponawiałabym prośby. Nie przez urazę, tylko wiem, że $z$ rozmowy wymuszonej nic by nie wyszło ${ }^{34}$.

Pojawia się tu jedno $\mathrm{z}$ kluczowych określeń, jakie $\mathrm{w}$ formie metatekstowych uwag powraca w reportażach Krall. Mianowicie wybiera ona taką historię, która jest „warta” tego, by opowiedzieć ją innym, która zasługuje na opisanie. Jakie kryteria o tym decydują? Krall formułuje je dość przewrotnie w reportażu Powieść dla Hollywoodu.

Jeziorska-Haładyj w analizie porównawczej tego tekstu oraz książki Król kier znów na wylocie stwierdza: „Relacja między bohaterką a reporterką jest szczególna, bo ich spotkanie nastapiło z inicjatywy bohaterki” (J 48). Powieść dla Hollywoodu rozpoczyna się od wyjaśnień pierwszoosobowej narratorki, w jaki sposób doszło do nawiązania kontaktu z przyszłą bohaterka jej reportażu: „Pani, której nie znam, zadzwoniła $z$ wiadomością, że pani, której nie znamy obie, chciałaby mieć o sobie książkę. Tę ksiażkę miałabym ja napisać” (H 5). W odpowiedzi na tę propozycję reporterka-narratorka zadała pośredniczce dwa bardzo konkretne pytania: owej pani.

- Czy jej życie zasługuje na opisanie? - spytałam, ale moja rozmówczyni nie miała pojęcia o życiu

- Czy ona mi zapłaci? - spytałam. [H 5]

Powtórzyła je potem w liście (wysłanym do Izraela) do samej zainteresowanej powstaniem książki na temat jej własnego życia:

Był to krótki, rzeczowy list człowieka interesu. „Podobno chce pani mieć książkę o sobie - pisałam. - Jeśli pani życie nadaje się na książkę, napiszę ją, ale, oczywiście, to musi kosztować”.

Nigdy nie pisałam podobnych listów, ale też nigdy przedtem nie miałam córki-emigrantki. [H 5]

Trudno nie zauważyć autoironii pojawiającej się w wypowiedziach reporterki-narratorki. Według Dobiegały w tekstach Krall taki zabieg „rozładowuje patos, pozwala [...] utrzymać dystans w stosunku do samej siebie i nie wpaść w pułapkę wielkich słów" 35 . Reporterka autoironicznie podchodzi do swej reakcji na propozycję napisania tekstu. Traktuje ja jako opłacalne zlecenie, rodzaj usługi do wykonania. Tym razem nie wspomina nic o Wielkim Scenarzyście czy dziwnym zbiegu okoliczności, dzięki któremu mogła poznać kolejną historię. Daje do zrozumienia, że z powodu nowej sytuacji życiowej jej motywacja, aby podjać się opisania losów kobiety mieszkającej w Izraelu, ma charakter głównie finansowy: „Za dwa bilety [lotnicze] do córki - pomyślałam - mogę wynając się na murzyna do każdego życia" (H 5). 
W podobnej tonacji utrzymane są rozmowy telefoniczne przeprowadzane $z$ przyszłą bohaterką reportażu. Podczas nich reporterka-narratorka próbuje się przekonać, czy opowieść Żydówki uratowanej z Zagłady spełnia warunki niezbędne do tego, by znaleźć się w książce:

- Dużo było ksiażek o Oświęcimiu - powiedziałam rozczarowana.

- Ja wiem - powiedziała ewentualna bohaterka - ale ja byłam inaczej.

- Nic lepszego od Borowskiego i od Primo Levi już się nie napisze... [H 6]

W trakcie dyskusji reporterka okazuje się zawiedziona tym, jak „pospolitą” historię ma do przekazania jej interlokutorka. Nie warto publikować kolejnych wspomnień z obozu Auschwitz - uznaje Krall. Na dowód przywołuje klasyków literatury lagrowej, co ma ostatecznie skłonić ocaloną do rezygnacji z powziętego zamiaru. Rozmowa zaczyna przybierać dość absurdalny charakter: kobieta usilnie stara się przekonać reporterkę, że jej przeżycia - ze względu na swą wyjątkowość i atrakcyjność - jednak powinny wzbudzić zainteresowanie czytelników. Dodaje zachęcająco: „Byłam i w paru innych miejscach - powiedziała moja e. b. (ewentualna bohaterka)” (H 6).

Według mnie w analizowanym reportażu (auto)ironia ulega rozszczepieniu i wymierzona jest zarówno w reporterkę, potencjalnych odbiorców jej tekstu, jak i w samą ocaloną. Ale po kolei. Reporterka-narratorka wciąż powraca do szczegółów negocjacji finansowych prowadzonych $\mathrm{z}$ izraelska interlokutorką ${ }^{36}$. Znajduje dla powierzonego sobie zadania (,usługi”) odpowiednią formułę: „Na Zachodzie jest [ono] częstym zajęciem niezamożnych literatów. Mówi się o takim ghost-writer. Pisarz-duch. Czyli "murzyn" piszaç anonimowo, za kogoś, za pieniądze" (H 5). Kategorię użytą przez Krall analizuje Dorota Krawczyńska w artykule na temat książki Król kier znów na wylocie:

Choć w pierwotnym sensie wyrażenie to oznacza kogoś, kto wynajmuje się do pisania, ale pozostaje nieujawniony, to w odniesieniu do pisarzy podejmujacych temat Zagłady nabiera całkiem nowych i bardzo adekwatnych znaczeń. Zatem jest to ktoś, kto pisze za tego, który opisać swojej historii nie potrafi, ale i niekiedy nie może - z tej przyczyny, że nie ocalał z Zagłady. Jest też i duchem w tym znaczeniu, jakie nadał egzystencji piszącego po Zagładzie Henryk Grynberg - określając samego siebie jako istniejącego i nieistniejącego zarazem, ocalałego, lecz martwego lub raczej nie w pełni uczestniczącego w świecie żywych. [...] Ghost-writer to pisarz-duch i pisarz duchów, medium i kreator zgładzonych egzystencji. Kontrakt zawarty w takich warunkach ma zatem wymiar symboliczny ${ }^{37}$.

W Powieści dla Hollywoodu ironiczne sformułowania reporterki-narratorki na własny temat zdają się więc w głównej mierze wynikać ze świadomości, że to targowanie się (o wysokość stawki i w ogóle o samą zgodę na napisanie tekstu) odbywa się z ocaloną z Zagłady. Wszak Krall wielokrotnie podkreślała, o czym już wspominałam, jaką wage przywiązuje do powierzanych sobie historii: „W każdej

Zob. H 7: „Wymieniłam kwotę, którą była równowartość dwóch biletów do Kanady w obie strony plus na telefony - też do Kanady.

- Dobrze - powiedziała moja e. b. [tj. ewentualna bohaterka], a ja natychmiast pomyślałam $\mathrm{z}$ żalem, że powinnam podać kwotę trochę wyższą".

37 D. Kr a w c zy ń s ka, O nagim królu i dwakroć zdradzonej królowej. „Res Publica Nowa” 2006, nr 4, s. 129. 
jest coś nowego, co nie zdarzyło się innym ludziom. Co uzupełnia wiedzę"38. Wydaje się, iż chciałaby opisać je wszystkie. W rozmowie z Michałem Nalewskim, który przypomniał zapewnienie reporterki, że Biała Maria to już jej ostatnie dzieło, stwierdziła:

Jest ostatnią [Biała Maria], ale się nie kończy. Nie zdawałam sobie z tego sprawy, kiedy mówiłam, że to koniec. Ale ledwie książka się ukazała i zaczęły się spotkania z czytelnikami, pojawili się ludzie, którzy chcieli mi opowiadać dalszy ciag. Oni znają jeszcze innych ludzi. A ci inni ludzie są zahaczeni o jakieś zdarzenia. Te zdarzenia o inne zdarzenia... Nie mam wyjścia, muszę pisać ${ }^{39}$.

Jednak, z oczywistych powodów, Krall stoi przed koniecznością ciagłego dokonywania wyboru, które spośród opowiadanych historii mogą znaleźć się w jej ksiażkach. Decydujące znaczenie ma tu uznanie przez reporterkę, że „zasługują na opisanie".

W tomie To ty jesteś Daniel reporterka-narratorka przytacza rozmowę $\mathrm{z}$ ocalonym, podobną do tej, jaką odbyła $z$ bohaterką reportażu Powieść dla Hollywoodu. W trakcie spotkania mężczyzna również prosił o opisanie jego losów: „Przybysz z Kanady przychodzi spytać mnie, co można zrobić z jego życiem. Czy na przykład można je opisać w książce” (T 57). Krall po zapoznaniu się z jego historią nie zgadza się na jej opracowanie i publikację. Uzasadnia swą decyzję tym, że już o takich wydarzeniach pisała, i sugeruje rozmówcy: „Proszę zanieść tekst do archiwum, ktoś kiedyś go przeczyta” (T 58). Kanadyjczyk, podobnie jak kobieta z Izraela, reaguje emocjonalnie i usiłuje przekonać reporterkę o wyjątkowości (czy raczej: fabularnym potencjale) swoich przeżyć. Streszcza je, wykorzystując nieomal schemat powieści przygodowej: „Zostaję sam. Uciekam. Łapią mnie. Wiozą. Obóz. Uciekam. Ukrywam się” (T 58). I zadaje reporterce fundamentalne pytanie: „Tego pani jeszcze za mało? Tego nie dosyć pani?” (T 58) - na co ona odpowiada: „Dosyć. Na życie dosyć. Na ksiażke za mało" (T 58). Jej słowami oburzony jest J. (tak w tekście), świadek tego dialogu:

Jak ty z nim rozmawiałaś? mówi J. po wyjściu gościa z Kanady. Serce ci nie pęka, kiedy tak rozmawiasz?

Nie pęka, mówię $z$ dumą, idiotyczną cokolwiek.

Usprawiedliwiam się. Nie dałoby się pisać $z$ pękniętym sercem.

Nic nie jest bardziej całkowite niż pęknięte żydowskie serce, powiedział Mendel z Kocka, ale J. nie zna, na szczęście, żydowskich cadyków. [T 58]

Także tutaj w wypowiedziach reporterki-narratorki występuje autoironia. Krall przedstawia tę rozmowę $\mathrm{z}$ ocalonym jako przykład jednej $\mathrm{z}$ wielu podobnych, które odbyła w ciagu swojej pracy. Za każdym razem przebiegaja one jakby według tego samego scenariusza:

Przyjeżdżają zewsząd, najchętniej latem.

Z plikami kartek.

Z tym samym uroczystym tekstem: oto jest... [T 57] 
Za każdym razem uratowani Żydzi proszą reporterkę o opisanie ich losów. Liczba tych historii jest przytłaczająca, nie do ogarnięcia, bo wciąż dochodzą nowe. To świadectwa Zagłady. Jak podjąc decyzję, które z nich zasługują na przedstawienie? Sama konieczność takiego wyboru okazuje się nieetyczna. I dlatego reporterka, relacjonując typową rozmowę $z$ ocalonymi, stosuje autoironię. Podkreśla w ten sposób, że zdaje sobie sprawę z popełniania pewnego nadużycia, z uzurpacji - bo gdy niektóre historie opisuje, to inne przecież pomija. Jednocześnie wie, iż w tej sytuacji brakuje właściwego rozwiązania ${ }^{40}$. Jej nieugiętość $\mathrm{w}$ trakcie spotkania z gościem $z$ Kanady, może nawet okrucieństwo (co sugerował J.), to rodzaj samoobrony przed zalewem zagładowych opowieści, przed wzięciem na siebie zobowiązania, którego nie da się spełnić. Krall potrafi odmawiać prośbom swoich rozmówców, nie pęka jej wówczas serce. A jednak, jak się okazuje, nie jest wolna od wyrzutów sumienia. Poprzez przywołanie słów cadyka $z$ Kocka podważa przekonanie o słuszności własnej postawy. Autorka książki Zdażyć przed Panem Bogiem, opisując losy ocalałych z Zagłady, znajduje się zatem w położeniu zakładającym trwaty konflikt wewnętrzny o charakterze etycznym.

W tym kontekście jej formuła „zasłużenia na opisanie” również zyskuje autoironiczny wydźwięk. Bo co w ostateczności kieruje reporterką-narratorką przy wyborze opowieści? Jeśli uwzględni się jej wypowiedzi przedstawione w Powieści dla Hollywoodu i we fragmencie z tomu To ty jesteś Daniel - mogłoby się wydawać, że przede wszystkim musi ona uznać przeżycia za niepowtarzalne, za takie, które się nikomu wcześniej nie przydarzyły. Według - co trzeba raz jeszcze podkreślić: przewrotnych - stwierdzeń reporterki na niepowodzenie skazane jest powielanie w tekście zagładowych scenariuszy ${ }^{41}$, w których dominują elementy typowe (takie jak ucieczka $z$ transportu czy uwięzienie w Auschwitz), nie zaś niezwykłe. Oto bowiem ksiażza może okazać się nudna, przewidywalna, pozbawiona elementów sensacji, a więc - mało atrakcyjna. W ten sposób autoironia Krall trafia pośrednio także w czytelników i ich - nieprzystające do tematyki Zagłady - upodobania ${ }^{42}$.

W analizowanych reportażach, przede wszystkim w Powieści dla Hollywoodu, au-

Zob. Ciéślik (op. cit.):

„Kiedyś mówiła mi pani o pewnym człowieku, który przyszedł opowiedzieć pani swój okupacyjny los. Tu uciekałem, tam do mnie strzelali...

- A ja powiedziałam, że tego za dużo jest na życie, ale za mało na literaturę.

- Ale zapis tej rozmowy znalazł się w książce To ty jesteś Daniel.

- Bo zawsze mam poczucie winy w takich sytuacjach. Kiedy ktoś przychodzi do mnie ze swoim życiem, a ja wiem, że nie napiszę. Bo już napisałam. Albo inni napisali. Albo nie dam rady. Albo nie mam siły... Coraz częściej nie mam siły".

41 Nawiązuję tu do określenia Głow iń s k i e go (op. cit., s. 205-206): „scenariusz z reguły ma pewne ogólne ramy, wyznaczone przez eksterminację, rasizm, bezwzględne okrucieństwo i ich konsekwencje. W scenariuszu tym role $z$ góry zostały rozdane, ale wypełnia się on jednostkowym losem [...]. Biografia holocaustowa ze wszystkimi swoimi elementami typowymi i niezwykłościami stała się podstawową formą opowiadania o losie tych, których życie zakończyć się miało w gettach i w obozach śmierci, jeśli zaś zostało uratowane, to za sprawą niezwykłych wysiłków i zbiegów okoliczności [...]".

42 Warto tu przywołać rozmowę z H. Krall na temat Białej Marii, przeprowadzona przez W. Tochm a n a (Nieopłakanie. „Duży Format”. Dodatek do „Gazety Wyborczej” 2011, nr z 30 IV). Bohaterka 
toironia służy Krall w głównej mierze do tego, by podając w wątpliwość jednoznaczny sens zawartych w tekście wypowiedzi, umożliwić refleksję nad tymi elementami jej własnego warsztatu, które odnoszą się do kwestii etycznych. Ta „wspaniała opowiadaczka życiorysów z czasów Zagłady" 43 wskazuje na rozmaite, nieusuwalne dylematy związane $\mathrm{z}$ opisywaniem losów ocalonych. Dylematy owe dotyczą nie tylko spraw fundamentalnych, jak dokonywania wyboru spośród powierzonych historii czy nawet samego sposobu prowadzenia rozmowy i ustalania tego, co się wydarzyło. Reporterka zaświadcza też o swoich zmaganiach z oczekiwaniami interlokutorów co do kształtu samej opowieści.

\section{Światowy hit o Żydach i miłości}

W Powieści dla Hollywoodu reporterka-narratorka początkowo określa kobietę z Izraela, która zwróciła się z prośbą o napisanie o niej książki, jako „ewentualną bohaterkę" (samą siebie, co warto przypomnieć, nazywa „ghost-writerem”). Biorąc pod uwagę ową charakterystykę, Krawczyńska stwierdza:

nie sposób ukryć umowności tej sytuacji. Wyraża się ona w powracającej formule, mówiącej o - nieco parafrazując - ewentualnej bohaterce ewentualnej opowieści o życiu ewentualnie zasługującym na opisanie w mojej-nie mojej książce. W słowach tych zawiera się - choć przecież niewyrażone wprost pytanie o etyczno-ontologiczny wymiar tego rodzaju pisarstwa. Kto mówi? Kto pisze? O kim i dla kogo? A przede wszystkim: do kogo należy opisywana historia? ${ }^{44}$

\section{W Słowniku literatury polskiej XX wieku Kąkolewski podkreśla:}

W trakcie pracy nad reportażem, w seansach, często licznych, nasuwających analogię z portretowaniem, bohater mówi: „moje życie to gotowy dramat”. Ma świadomość ustrukturowania swej historii. Czasem protestuje przeciw sposobowi widzenia go przez autora czy wypreparowaniu z jego życia wybranego, najważniejszego dla reportażysty fragmentu. Okazuje np. niezadowolenie, gdy autor nie notuje jakiegoś fragmentu jego opowieści ${ }^{45}$.

W reportażu Powieść dla Hollywoodu Izolda R. - zgodnie $z$ wyjaśnieniami reporterki-narratorki, tak brzmiało prawdziwe imię bohaterki chcącej książkę wydać pod nazwiskiem „Maria Pawlicka”, jednym z tych, które nosiła, ukrywając się podczas okupacji - dość dokładnie przedstawia swoje oczekiwania co do zamawianego tekstu:

Ta książka była jej potrzebna na film.

Książka powinna stać się światowym hitem, a film powinien powstać w Hollywood. [H 7]

wywiadu - nawiązując do książki W. To ch mana Dzisiaj narysujemy śmierć (Wołowiec 2010) - krytycznie odnosi się do przeważających, wedle reportera, oczekiwań współczesnych odbiorców co do tekstów o Zagładzie:

„- Czy to, co pani pisze, jest próbą, nie chcę powiedzieć słowa "ucieczki", ale próbą zmierzenia się z tym schematem, jakim jest żydowski los? Jak o tym opowiadać? Nowa książka musi być nowa, kolejna historia musi być nowa.

- Dlaczego?

- Żeby panią dalej czytali. Dzisiaj książka musi być atrakcyjna.

- Mam atrakcyjnie opowiadać o Zagładzie? Pan chciał o Rwandzie napisać atrakcyjnie?” 
Izolda przywołuje nawet tytuł powieści, na której miałaby się wzorować reporterka:

Taki gruby buch, pani Haniu - tłumaczyła mi bohaterka. - Przynajmniej jak Ingeborga Kellermana. Nie czytała pani? To najpiękniejsza rzecz o miłości. Tak się w niej wszystko czuje - tę jego rozpacz, tę miłość, ten ból... Już mnie pani rozumie? [H 10]

Ocalona określa też korzyści (emocjonalne i materialne), które pragnie osiagnąć dzięki publikacji swoich wspomnień: „Jej życie - mówiła - było niezwykłe, jej problemy były niezwykłe, chciałaby opowiedzieć o nich ludziom, a poza tym chciałaby zarobić pieniądze na parę rzeczy” (H 8).

Jeziorska-Haładyj wskazuje, jakie wzorce literackie ukształtowały „smak” Izoldy:

XIX-wieczna powieść realistyczna, późniejsza powieść popularna. Izolda oczekuje właściwego tej odmianie gatunkowej „epickiego rozmachu”, choć przy zachowaniu całkowitej wierności faktom. [J 44-45]

\section{Badaczka stwierdza:}

książka nie była dla niej celem samym w sobie. Znane z młodzieńczych lektur konstrukcje fabularne zauważa Izolda w hollywoodzkim filmie. Pragnie, by „gruby buch” nadawał się na „film dla Hollywoodu” - wzruszający, nawet łzawy, przewidywalny, dynamiczny, zrozumiały dla każdego melodramat, filmowy przebój, dzieło kultury popularnej, z Liz Taylor w roli głównej [...]. [J 45]

Biorąc pod uwagę rozpoznania zawarte w artykule Jeziorskiej-Haładyj, w projektowanym przez Izoldę filmie, który ma stanowić zwieńczenie historii jej życia ${ }^{46}$, można odnaleźć podstawowe założenia... estetyki kiczu (pragnę podkreślić, że nie używam tu terminu „kicz”, aby dokonywać jakiejkolwiek oceny historii Izoldy ${ }^{47}$, lecz by móc odnieść się do pożądanego przez nią sposobu przedstawienia jej doświadczeń w powieści i filmie).

Aby taki film mógł powstać, najpierw potrzebna była książka, zamówiona u reporterki. Miała stanowić tylko pośredni etap na drodze do kinowego hitu o wojennych losach Izoldy. Jak poradziła sobie $z$ tymi wymaganiami ocalonej reporterka? W autotematycznej Powieści dla Hollywoodu opisuje swoje próby sprostania im, lecz także na różne sposoby z nimi polemizuje, a momentami po prostu zawiesza przedstawianie losów Izoldy, by przejść do innych historii. Mimo trudnych relacji

Wydaje się, że Izolda nie tylko traktuje powstanie filmu jako ostateczny cel opublikowania swoich wspomnień, ale wręcz utożsamia własne życie z historią filmową, w której odgrywa główną rolę zob. H. K r al1, Król kier znów na wylocie. Warszawa 2006, s. 15: „Spróbuje wnuczce coś opowiedzieć, historię sprzed pół wieku [...], niezwykłą historię, więc wnuczka klęcząca u jej kolan będzie słuchała z zapartym tchem. Na koniec ona przymknie oczy i szepnie - potem nie było już nic. Całkiem jak w Rose-Marie, amerykańskim przedwojennym filmie według operetki Frimla z Jeanette MacDonald i Nelsonem Eddym w rolach głównych. Rose-Marie, stara już, lecz wciąż piękna, siedziała w fotelu, snuła opowieść, zaś film całe jej życie ukazywał. Z tym, że MacDonald nie przymykała oczu. To była Vivien Leigh jako Lady Hamilton w zupełnie innym filmie, ale nic nie szkodzi”.

47 Krall w jednym $z$ wywiadów prasowych podkreślała (Bi ela s, op. cit., s. 22): „Scena w powieści może być kiczem, w reportażu jest to niemożliwe. Po prostu dlatego, że pojęcie kiczu nie odnosi się do prawdziwego życia”. 
z bohaterką Krall okazuje się ,jedyną powiernicą całej opowieści, my zaś - odbiorcami powierzonej narracji” 48 .

Reporterka już na początku swojej pracy nad historią ocalonej czyni zasadnicze przeciwstawienie: „książka o Izoldzie R., pisana dla mnie, nie dla Hollywoodu, powinna się zaczynać następująco: [...]” (H 9), podkreślając tym samym zupełną rozłączność tych dwóch stylów opowiadania. Zgodnie $\mathrm{z}$ poetyką każdego $\mathrm{z}$ nich przedstawia też dwa (wykluczające się) początki narracji o losach Żydówki. Najpierw opisuje wydarzenia „dla siebie”, szybko jednak przekonuje się, że taki tekst byłby zbyt trudny do interpretacji - zanadto osadzony w kontekście historycznym - dla masowego, w dodatku pochodzącego spoza Europy, czytelnika. Krall za pomoca kilku słów-kluczy, kilku drobnych obserwacji wyprowadzonych z perspektywy bohaterki zarysowuje sytuację w getcie warszawskim. I zauważa:

żaden amerykański czytelnik nie zrozumiałby, o co chodzi: jaki tyfus? jaki mur? co to za zwłoki? Kto wie nawet, czy przy słowach „drugiej wojny światowej” nie należałoby podać w nawiasach dat: (19391945). [H 10] $]^{49}$

W Powieści dla Hollywoodu reporterka-narratorka zaznacza swój dystans, a nawet niechęć wobec oczekiwań Izoldy: „Rozumiałam [...], że nie mam żadnego pomysłu na gruby buch, w którym się czuje rozpacz i miłość" (H 10). Powtórzenie słów bohaterki prowadzi tu nieomal do ich ośmieszenia. Ironia Krall manifestuje się także już w tytule reportażu, nawiązującym do prośby ocalonej. W toku opowieści nazwa amerykańskiej wytwórni filmowej powraca wielokrotnie, odmieniana prawie przez wszystkie przypadki gramatyczne. Nadaje jej to pozornie familiarny charakter, zdaje się wręcz przybliżać cel, jakim było powstanie „światowego hitu” o życiu Izoldy - najpierw książkowego, a potem filmowego. Aby sprostać podjętemu zobowiązaniu, Krall postanawia poprosić o pomoc Krzysztofa Kieślowskiego: „Stał się światowym reżyserem i powinien wiedzieć, jak się dla Hollywoodu pisze” (H 10). Miał on opracować początek opowieści: „parę zdań, typowy Hollywood, żebym tylko zobaczyła, jak to się robi” (H 11). Reporterka nieomal sarkastycznie odniosła się do otrzymanego wówczas tekstu ${ }^{50}$. Warto przytoczyć wywiad prasowy z Krall, gdzie wprost wyraziła ona swoją opinię ten temat:

P. Czapliński, Hanna Krall o mitości ocalonej z Zagłady. „Kultura”. Dodatek do: „Dziennik. Polska-Europa-Świat” 2006, nr z 16 VI, s. 82. H. Krall w wywiadzie prasowym udzielonym J. Sobolewskiej (Moi bohaterowie sa prawdziwi. „Dziennik. Polska-Europa-Świat” 2007, nr z 12 XI, s. 22) wspominała o tym, jak Izolda próbowała, bez powodzenia, powierzyć swoje przeżycia pisarzom, a także najbliższym osobom:

"- Opowiadała swoją historię innym: Wygodzkiemu, Szczypiorskiemu, Kazimierzowi Brandysowi, ale nie chcieli jej słuchać. Opowiadała swoim wnuczkom, ale nie rozumiały jej, bo nie mówiła ich językiem.

- Została jej tylko pani.

- Uważałam, że ma okropne upodobania literackie, ale zasługuje na pamięć".

Autorka zastosowała taki zapis w opowieści Król kier znów na wylocie. W rozmowie z B. Kę c zk o w s k ą (Ta ksiażka nie jest dla pani, droga Izoldo. „Gazeta Wyborcza Stołeczna” 2006, nr 113, z 16 V, s. 9) stwierdziła z goryczą: „To wygląda jak żart. Ale nie jest żartem. Moim młodym czytelnikom mogą się mylić daty, czy to odsiecz wiedeńska, powstanie styczniowe, czy II wojna światowa. Staram się ułatwić im lekturę".

Zob. H 11: „Tak, to było to. Pojętnie uzupełniłam tekst scenerią pierwszego rozdziału: brzozowym 
Krzysztof bardzo pracowicie napisał osiem stron, które wydały mi się dość idiotyczne i lekko grafomańskie, ale on powiedział z przekonaniem: - Tak właśnie pisze się dla Hollywood. Kilka stron wykorzystałam, ale nie dałam rady długo trzymać się tej konwencji. Książka stała się więc mieszaniną tego, co chciała Izolda, i tego, co ja chciałam ${ }^{51}$.

Zgodnie $z$ metatekstowymi uwagami reporterki porzuciła ona „pisanie dla Hollywoodu” w momencie, gdy miała przystąpić do przedstawienia dokonującej się Zagłady:

Kiedy w relacji Izoldy R. zamykano getto, kiedy na ulicach pojawiły się zwłoki ludzi zmarłych z głodu i na tyfus, przykryte gazetami, które nad ranem mijała, po raz pierwszy pomyślałam, że chyba dam sobie spokój z Hollywoodem. [H 12]

Krall nie zdecydowała się więc na to, aby wykorzystać możliwości kiczu (do czego ostatecznie sprowadzały się oczekiwania ocalonej oraz podpowiedź Kieślowskiego) jako „tłumacza zdarzenia historycznego” 52 :

Bardzo możliwe, że Amerykanie potrafiliby taki film nakręcić - zbudować makietę getta, zaludnić ją wychudzonymi ludźmi, ułożyć wzdłuż ulic manekiny przykryte gazetą - Amerykanie potrafią wszystko, ale mnie opuściła wena, której wymaga gruby buch. [H 12]

Reporterka nie chciała także za pomocą upraszczajacych, romansowych schematów kreować emocji czytelników (co w konsekwencji mogłoby prowadzić do nadmiernego identyfikowania się ich $z$ bohaterami). Nie próbowała ułatwiać zrozumienia Zagłady. Była wręcz przekonana, że tego, co się stało, „zrozumieć się nie da, można tylko opowiadać konkretne zdarzenia” ${ }^{53}$. Czasami jednak to (nazbyt silne?) pragnienie opisywania poznanych historii - powodowało dylematy moralne.

\section{Wspaniała scena}

Kąkolewski, charakteryzując „stopnie obecności” reportera przy zdarzeniu, które ten chciałby przedstawić, przywołuje sytuację ukazaną przez Joségo Ortegę y Gasseta w eseju zatytułowanym $O$ dehumanizacji sztuki, kiedy to „nad łożem umierającego znajduje się jego żona, lekarz, reporter i malarz [...]"54. Filozof, zastanawiając się wówczas nad emocjami każdego z nich, stwierdza:

zagajnikiem, rozpalonym mchem i gorącym światłem, drżącym wśród gałęzi. "Przesunął rękę po jej szyi..." - dodałam i dalej już następował opis złotej skóry”.

M a rze c, op. cit., s. 22.

Ciekawie o funkcji kiczu w kontekście „amerykanizacji” Holokaustu w filmie, rozumianej jako „dostosowywanie języka mówienia o tym wydarzeniu do odbiorcy”, pisze K. Krze mińs ka (Kicz $w$ kinie holokaustowym. „Zagłada Żydów. Studia i Materiały” nr $6\langle 2010\rangle$, s. 66): „Kicz będzie [...] służył jako specyficzny rodzaj tłumacza zdarzenia historycznego, które przez to, że jest obce, nieprzynależne bezpośrednio do continuum historycznego narodu amerykańskiego, musi zostać przeformułowane tak, aby społeczeństwo, czy precyzyjniej mówiąc: pamięć społeczna, mogła ten fakt przyswoić i wchłonać. Do tego procesu tłumaczenia wydarzenia na język zrozumiały dla wszystkich jest wykorzystana owa symboliczna wartość kiczu, jego uniwersalność i niezwykła elastyczność".

M. Dąbrowski, Grynberg i Krall: dwie strategie pisarstwa poholokaustowego. W: Dwa watki. Warszawa 2015, s. 248.

K. Ką kolews ki, Wokót estetyki faktu. W zb.: Reportaż, s. 91. Pierwodruk: „Studia Estetyczne” t. 2 (1965). 
zadania reportera pozwalają mu trzymać się z daleka; może on ograniczyć się do obserwacji. Dla niego wypadek jest tylko sceną, czystym spektaklem, z którego ma zdać sprawę na łamach gazety. W to, co się tu dzieje, nie angażuje żadnych uczuć, jest emocjonalnie wolny, jest osobą obcą ${ }^{55}$.

Kąkolewski dopowiada:

Reporterzy twierdzą, że często jedynym uczuciem, jakiego doświadczają, jest uczucie fascynacji zdarzeniem [...], będące sygnałem, że mają do czynienia z faktem niezwykłym, wartym opisania ${ }^{56}$.

Podobne emocje towarzyszą również Krall, przysłuchującej się opowieściom rozmówców o Zagładzie Żydów. $Z$ tego powodu reporterka zmaga się jednak z dylematami moralnymi. Uważa bowiem to swoiste „oczarowanie” wydarzeniem, postrzeganie go przede wszystkim jako pisarskiego wyzwania - za niestosowne.

W Powieści dla Hollywoodu reporterka-narratorka analizuje własną reakcję, gdy Izolda zrelacjonowała jej to, czego doświadczyła na Pawiaku, zobaczywszy matkę męża prowadzoną na rozstrzelanie. Za wszelką cenę chciała unikną́ jej spojrzenia, w obawie że teściowa ją rozpozna i tym samym zdradzi również jej, Izoldy, żydowskie pochodzenie. Słysząc to, Krall przyznaje:

Czułam, jak wypełnia mnie uczucie znane od lat, od kiedy zaczęłam pisać reportaże. To uczucie pojawiało się wtedy, gdy miałam przed sobą świetnego bohatera. Gdy miałam przed sobą - TEMAT. Izolda R. opowiadała mi, jak na podwórzu Pawiaka modliła się o szybszą śmierć dla matki, a ja myślałam, że to jest wspaniała scena. [...] - Jakby moje opisywanie było ważniejsze niż ich śmierć... - myślałam ze skruchą [...]. - Jakby one szły po to, bym je mogła opisać... A jednak - próbowałam usprawiedliwić się - ta rzecz powinna być zapisana. [...] Więc jeżeli należy to zapisać, powinno być zapisane dobrze, żeby ktoś, kiedyś, jeśli przeczyta... [H 22]

Można dostrzec, że w tych rozważaniach Krall daje wyraz kolejnej nieusuwalnej sprzeczności charakteryzującej jej twórczość. Oto reporterska „fascynacja zdarzeniem", o której wspominał Kąkolewski, okazuje się niestosowna w przypadku pracy nad opowieściami ocalałych czy świadków Zagłady. Wątpliwości autorki Hipnozy budzi konieczność znalezienia odpowiedniej formy językowej (artystycznej?), by móc te doświadczenia wyrazić. Krall uważa, że już samo myślenie o nich w kategoriach (przyszłego) tekstu wręcz przesłania to, co się wydarzyło. Długą historię tego rodzaju dylematów przypomina Katarzyna Chmielewska:

Spór o stosowność środków literackich w opowiadaniu o Zagładzie trwa od początku Zagłady. Wątpliwości co do wyboru języka i sposobu opowiadania towarzyszyły piszącym już w czasie Holokaustu i najczęściej wyrażały się w postaci radykalnego zwątpienia w możliwość opisu tego zjawiska oraz w uporczywych wysiłkach znalezienia nowych środków wyrazu ${ }^{57}$.

Krall akcentuje wszakże nieco mniej oczywisty aspekt owego wielkiego zderzenia Zagłady i języka: wskazuje nie tyle na niewyrażalność tych doświadczeń, ile raczej na ich bezbronność wobec językowych (i innych) przedstawień. Podkreśla

J. Ortega y Gas set, Odehumanizacji sztuki. „Twórczość” 1957, nr 12. Cyt. za: Ką kolew ski, Wokót estetyki faktu, s. 91.

56 Ką kolews ki, Wokót estetyki faktu, loc. cit.

57 K. Chmielewska, Literackość jako przeszkoda, literackość jako możliwość wypowiedzenia. W zb.: Stosowność i forma. Jako opowiadać o Zagładzie? Red. M. Głowińs ki [i in.]. Kraków 2005, s. 21. 
swoista przewagę tekstu nad rzeczywistością, a nie odwrotnie. Zdaje sobie sprawę, że niektóre sytuacje graniczne ${ }^{58}$ może np. opowiedzieć atrakcyjnie, tak by znalazły uznanie czytelników przede wszystkim jako estetycznie udane opisy, jako „wspaniałe sceny”. Zmagając się z poczuciem winy i wstydem, ma jednak świadomość, że spełnienie moralnej powinności relacjonowania tego, co się stało (omówiłam to zagadnienie we wcześniejszej części pracy), może nastąpić tylko w następstwie wyboru odpowiedniej formy językowej. Aby wzmocnić to przeświadczenie (i „usprawiedliwić się”), reporterka nadaje mu postać nieomal przykazania („powinno być zapisane dobrze”), mimo że jednocześnie wątpi w zrozumienie tych wydarzeń - bez względu na sposób ich przedstawienia - przez kogokolwiek („Czy można zrozumieć modlitwę Izoldy R., nie idąc nigdy podwórzem Pawiaka?”, H 23).

W często cytowanej przez badaczy rozmowie $z$ Bielas wspominała Krall o trudnościach z opisaniem masowego rozstrzeliwania Żydów w Dubnie, o którym opowiedział jej Axel von dem Bussche ${ }^{59}$. Jej wyjaśnienia wskazują na nierozerwalny splot kwestii warsztatowych i etycznych:

Nadzy Żydzi zstępowali do grobu, a ja musiałam znaleźć dla tego formę. W takich chwilach dzwonię do przyjaciół. Dawniej dzwoniłam do Marysi Leszczyńskiej albo do Krzysztofa Kieślowskiego. Oboje już nie żyją. Ostatnio zadzwoniłam do Ruty Sakowskiej, która jest historykiem i pisze bardzo mądre książki o getcie warszawskim. Dzwoniłam po rozgrzeszenie.

Wiem, co ludzie mi powiedzą, ale ja chcę to usłyszeć. Chcę usłyszeć, że jeśli to, co piszę, ma zrobić wrażenie na czytelniku, muszę nadać temu formę. Tragedie pozbawione formy są czymś bezwstydnym. Forma oddala na odległość, która pozwala w ogóle opowiadać.

Bez formy znalazłabym się w tym dole pełnym trupów ${ }^{60}$.

Czy „forma” oznacza tu literackość? W interpretacji Przemysława Czaplińskiego utożsamienie tych pojęć pozostaje bezsporne. Co więcej, uznaje on wywody Krall za przejaw nowatorskiego pojmowania związków między opisywaniem Zagłady a literackością. Badacz prezentuje bardzo szerokie rozumienie tej kategorii. Dla niego każdy tekst nosi znamiona literackości:

Współczesne literaturoznawstwo od wielu lat odkrywa [...], że literackość istnieje poza wyborem, że nawet najbardziej niekonwencjonalny tekst pozostaje tekstem, a więc kombinacją rozmaitych porządków kompozycyjnych i stylistycznych. Stwierdzenie to dotyczy również dokumentów, co znaczy, że także one należą do uniwersum literackości. [...] czytanie tekstów holocaustowych musi uwzględnić owo konieczne zapośredniczenie, jakie wchodzi pomiędzy język i rzeczywistość ${ }^{61}$.

Krall zdaje sobie sprawę, iż każdy opis faktów jest w pewnym sensie inwazyjny, że narzuca własny porządek, zawiera czyjś punkt widzenia, wymaga użycia określonego schematu narracyjnego i adekwatnego wobec niego stylu, podlega presji

Odwołuję się tu do klasycznego rozróżnienia K. J a s per s a (Sytuacje graniczne. Przeł. A. S taniewska. W: R. Rudziński, Jaspers. Warszawa 1978, s. 188), który pisał: „Sytuacjami granicznymi nazywam to, że stale znajduję się w jakichś sytuacjach, że nie mogę żyć bez walki i cierpienia, że biorę na siebie winę i nie mogę tego uniknąć, wreszcie, że muszę umrzeć".

59 Zob. ciekawy artykuł J. Le o cia ka (Wyjście z grobu. „Teksty Drugie” 2004, nr 5) na temat relacji osób, którym udało się przeżyć własną egzekucję bądź które były świadkami takich przypadków.

60 Bielas, op. cit., s. 22.

61 P. C za plińs ki, Zagłada jako wyzwanie dla refleksji o literaturze. „Teksty Drugie” 2004, nr 5, s. 20. 
oczekiwań czytelników, a w przypadku reportażu również bohaterów ${ }^{62}$, słowem stanowi tylko jedną $\mathrm{z}$ wielu wersji wydarzeń, niekoniecznie najbliższą ich rzeczywistemu przebiegowi. Dlatego Krall potrzebuje „rozgrzeszenia”. Traktuje te wszystkie pisarskie zabiegi jako, co prawda, nieuniknioną, lecz - ingerencję w materię faktów, w samo tworzywo, na podstawie którego ma powstać opowieść:

nawet w prostej formie musi być zachowana jakaś kompozycja, jakiś rytm. I za każdym razem, kiedy tym scenom nadaję rytm, mam poczucie niestosowności. Oczywiście, mogę się rozgrzeszyć, że to powinno być jakoś napisane, aby czytelnicy chcieli wziąć książkę do ręki. Ale pytanie o to, gdzie jest dopuszczalna granica, stale do mnie powraca i nie potrafię na nie odpowiedzieć63.

Aby przekazać odbiorcom opowieść o masowym morderstwie w Dubnie, trzeba znaleźć dla niej taką formę, która, po pierwsze, pozwoli reporterce na zachowanie dystansu emocjonalnego, umożliwiającego $\mathrm{w}$ ogóle przystąpienie do pisania; po drugie, uwzględni perspektywę ofiar (co analizowałam w poprzedniej części pracy); i wreszcie, po trzecie - która okaże się atrakcyjna dla odbiorców, zrobi na nich wrażenie. Jak w tekstach Krall dochodzi do uspójnienia tych wszystkich, raczej sprzecznych, uwarunkowań? W cytowanej rozmowie z Janowską i Mucharskim reporterka przywołuje kategorię stosowności. Zaznacza jednak od razu, że nie potrafi precyzyjnie określić, jaka opowieść zasługuje na takie miano, a kiedy jej własne pisarstwo już tę granicę przekracza. Głowiński, definiując decorum, stwierdza:

Wyznacza ono i wskazuje to, co wydaje się właściwie użyte, co znajduje się na właściwym miejscu. Oczywiście, nikt nie skodyfikował zasad, jakim powinna zostać wierna narracja holocaustowa [...]; byłoby to niemożliwe, trudno jednak zaprzeczyć, że istniał i w jakiejś mierze istnieje nadal pewien zespół reguł, który sprawia, że ta literatura może funkcjonować - i liczyć na aprobatę. Zespół reguł nie tylko pisarskich, także moralnych, ideowych i [...] dobrego smaku ${ }^{64}$.

Wydaje się, że to właśnie kierowanie się względami stosowności przez Krall umożliwia jej choć częściowe przezwyciężenie sprzeczności charakterystycznych dla pisania na temat Zagłady. W każdym razie to na te - nieskodyfikowane, lecz przecież uznawane za obowiązujące - reguły powołuje się reporterka, gdy odrzuca czy krytykuje pomysły Izoldy $\mathrm{R}$.

\section{Rozczarowanie}

Kąkolewski, mówiąc o relacji między autorem a bohaterem reportażu, zauważa:

Reporter, w odróżnieniu od pisarza, nie tworzy fabuły ani nie powołuje do życia bohaterów. Oni żyją naprawdę. Działają niezależnie od woli i fantazji reportera, przeciwnie: mogą wolę reportera ograniczyć, występować przeciw niej. Bohater może nie chcieć stać się bohaterem reportażu, oceniać swoją rolę w jakichś wydarzeniach inaczej niż reporter i żądać sprostowania. Następuje spór o to, kim jest bohater, między nim samym a reporterem ${ }^{65}$.

C za plińs ki (loc. cit.) nazywa te kolejne warstwy „archeologią tekstu”.

Janowska, Mucharski, op. cit., s. 10.

Głowiński, op. cit., s. 209.

K. Kąk olews ki, Reportaż. W zb.: Reportaż, s. 67. Pierwodruk w: Teoria i praktyka dziennikarstwa. Wybrane zagadnienia. Red. B. Golka, M. Kafel, Z. Mitzner. Warszawa 1964. 
W Powieści dla Hollywoodu Krall zdaje relację z konfliktu, do jakiego doszło pomiędzy nią a Izoldą. Ocalona nie była zadowolona $z$ książki, która powstała na podstawie jej wspomnień. Rozczarował ją sposób przedstawienia wydarzeń i wizerunek głównej bohaterki.

- Strasznie mała ta powieść, pani Haniu - powiedziała nagle. - Miał być gruby buch, a wyszła książeczka.

- Taka powinna być - wyjaśniłam. - Książka o Marku Edelmanie była jeszcze krótsza. O sześćdziesiąt stron, o jedną trzecią. A była to książka o powstańcach getta...

- To było wszystko takie okropne - podjęła, jakby nie słysząc, co mówię - ta moja rozpacz, moje serce, moje łzy, a u pani? Parę zdań - i to już wszystko?

- Im większa rozpacz, tym mniej trzeba zdań, pani Izoldo. [H 32]

Trafnie płaszczyznę tego sporu określa Jeziorska-Haładyj:

Konflikt między bohaterką a reporterką nie przebiega na linii prawda-fikcja. Izolda nie pragnie, by jej historię przekształcić, upiększyć czy podkoloryzować. Przeciwnie: pilnuje wierności faktom w najdrobniejszych szczegółach. [...] Spór toczy się o kwestie estetyczne, nie epistemologiczne: dla Izoldy słów jest za mało, dla reporterki - za dużo, pierwsza pragnie emocji, druga - powściagliwego dystansu. [J 46]

Jedno z zasadniczych zastrzeżeń ocalonej było związane z niewielką objętością tekstu. Izolda spodziewała się, że opowieść o jej losach, o wszystkich skrajnie trudnych doświadczeniach, zdoła wypełnić stronice „grubego buchu”. Tymczasem zamiast tego powstało, jak to $\mathrm{z}$ goryczą ujęła, „parę zdań”. Biorąc pod uwagę upodobania literackie Izoldy, wydaje się, iż uznaje ona już samą objętość książki za istotny wskaźnik jej wartości. Świadczyłoby o tym pogardliwe zdrobnienie zastosowane wobec otrzymanego tekstu: „książeczka”.

Ocalona domaga się, by reporterka uzupełniła opowieść o kolejne (znane sobie a celowo pominięte) opisy zdarzeń: „W ogóle: dodać, dodać, dodać” (H 35). Nie akceptuje dokonanej przez nią selekcji materiału66:

- To było, pani Izoldo - mówiłam. - Opisałam to w pierwszej wersji, ale musiałam skreślić, bo robiły się dłużyzny.

- Dłużyzny?! - wołała Izolda R. - Pani Haniu! Jakie dłużyzny! Ta scena z kopytkami oddaje przecież problem! [H 35]

Izolda nieprzychylnie odnosi się do decyzji usunięcia pewnych scen. W przeciwieństwie do reporterki uznaje je za niezbędne dla jasności i dramaturgii całej opowieści. Oburza ją określenie „dłużyzny”. Traktuje je nie jako wskazanie wady kompozycyjnej utworu, lecz niemal jako podważenie doniosłości własnych doświadczeń. W zapisie tych przeżyć nie odnajduje też stale wówczas towarzyszących jej intensywnych emocji. Według bohaterki formalna prostota i oszczędność tekstu wykluczają możliwość ekspresji „rozpaczy”, „serca” i „łez”. Izolda nie chce przyjąć do wiadomości wyjaśnień reporterki:

- Ja pani tyle opowiadałam... Myślałam, że to pani wykorzysta - mówiła coraz pewniej, z coraz wyraźniejszą nutą pretensji.

66 Kr all wskazuje na dylematy związane $\mathrm{z}$ tą częścią pracy nad reportażem w rozmowie $\mathrm{z}$ Tu s z y ńską (op. cit., s. 55): „Nie jest dobrze wiedzieć mało, ale jeszcze bardziej kłopotliwe, kiedy się za dużo wie, bo trzeba później rozstrzygnąc, co wolno z tą wiedzą uczynić”. 
Ogarniała mnie złość. Moja bohaterka zaczynała się zachowywać jak klientka, która dała krawcowej materiał, spodziewała się kreacji z zakładkami, szczypankami, bufami i falbaną, a otrzymuje suknię prostą i skromną.

- Im wspanialszy materiał, tym fason powinien być prostszy - powtórzyłam poprzednią myśl innymi słowami. [H 32-33]

$\mathrm{W}$ polemice $\mathrm{z}$ Izoldą reporterka wręcz aforystycznie wykłada fundamentalną zasadę swojego pisarstwa o Zagładzie ${ }^{67}$. Poirytowana, próbuje ułatwić rozmówczyni zrozumienie tej koncepcji za pomoca „krawieckiej” przenośni. To obrazowanie służy też do scharakteryzowania coraz bardziej napiętych relacji z ocaloną. Krall nazywa ją „klientką”, ponownie wskazując na roszczeniowa postawę bohaterki książki i, już bez autoironii, na materialny aspekt sprawy. Próbuje przekonać Izoldę, że zamówiony przez nią tekst nie mógł zostać napisany tak, jak ona sobie tego życzyła: „ma pani zły smak. Może nie zły... - poprawiłam się - tylko anachroniczny. Czy tradycyjny raczej...” (H 33). Opowieść o Zagładzie podporządkowana „anachronicznym” czy „tradycyjnym” upodobaniom musiałaby okazać się niestosowna, nie przystająca do tamtych doświadczeń. Takiemu osądowi, niemal powszechnie pojawiającemu się w refleksji autorów i badaczy zajmujących się tą problematyką, Krall daje wyraz w rozmowie $z$ Wojciechem Tochmanem:

Wie pan, Izolda jest przywiązana do tradycji literackiej, do sposobu pisania z czasów jej młodości. Historii o II wojnie światowej nie można opowiadać w dawny sposób ${ }^{68}$.

Reporterka, wbrew oczekiwaniom ocalonej - niejako w obronie jej własnej opowieści ${ }^{69}$ - nie decyduje się na wprowadzenie sugerowanych zmian. Wyjaśnia to Izoldzie w rozmowie telefonicznej:

- Dodaje pani?

- Dodaję. Ale zaraz skracam, bo to dodane okazuje się zbyteczne. [H 36]

Reporterka nie ulega też presji bohaterki, by usunąć pewne elementy tworzące jej wizerunek:

Dalej: skreślić niektóre słowa, na przykład: „pokorna”, ,potulna”, „przymilna”, „oddana”...

To było o niej. Tymi słowami charakteryzowałam bohaterkę, która była dzielna i wspaniała wobec całego świata, ale przy swoim mężu stawała się cicha i pełna pokory.

- Mowy nie ma, pani Haniu. Pokorna? Ja?! [H 35]

\section{Marek Miller zauważa:}

Bo jest rzeczą oczywistą i trzeba pamiętać o tym, że człowiek, z którym reporter nawiązuje kontakt, w pierwszym odruchu [...] stara się bronić, przedstawić siebie i swoje poglądy trochę inaczej, niż myśli naprawdę. Stara się mówić to, co mu się wydaje, że reporter chciałby usłyszeć ${ }^{70}$.

Wspomina o niej też w jednym z wywiadów prasowych (J a n ow s k a, M u c ha r s ki, op. cit., s. 10): „Nie uchodzi żaden ornament ani metafora. Forma powinna być jak najprostsza”.

W. To c h m a n, Droga do białych miejsc. Rozmowa z H. Krall. Na stronie: http://www.tochman.eu/ reporter.php?w_id=1 (data dostępu: 25 VI 2013).

69 Co ciekawe, jak zauważa reporterka-narratorka, sposób, w jaki Izolda opowiadała swoją historię, odbiegał od jej wymagań wobec ostatecznego kształtu książki: „O wszystkim tak mówiła - precyzyjnie, rzeczowo, jakby sama zapominała, że ma z tego wyjść wiadomy buch” (H 19).

70 M. Mille r, Reporterów sposób na życie. Warszawa 1983, s. 148-149. Cyt. za: Wolny, op. cit., s. 191. 
Izolda potraktowała sposób przedstawienia głównej bohaterki książki jako uzurpację ze strony reporterki. Nie zdołała odnaleźć w tym obrazie samej siebie. Uznała charakteryzujące ją określenia za zupełnie nietrafne. Zależy jej na utrwaleniu innego wizerunku, pozbawionego jakichkolwiek oznak słabości czy podległości. Jeziorska-Haładyj następująco komentuje pisarską postawę Krall:

Autorka tworzy [...] obraz bohaterki wbrew niej samej, wydobywa to, co miało pozostać w cieniu, nieuświadomione lub celowo ukryte. Wykracza poza ramy zawartej umowy, „zdradza” bohaterkę, samodzielnie kształtuje jej relacje $z$ odbiorca. [ $\mathrm{J}$ 50]

Podobne zastrzeżenia co do pisarstwa Krall formułowane były, często w niewybredny sposób ${ }^{71}$, już znacznie wcześniej. W roku 1981 podsumowuje je Krystyna Konecka:

Zdarzają się czytelnicy, którzy nie akceptują jej pisania. [...] Jest jeden generalny zarzut: że w reportażach źle odnosi się do swoich bohaterów. Że jest okrutna. Że za bardzo odsłania. Że pisze o nich rzeczy, których nie powinna ${ }^{72}$.

Sama Krall w wywiadach prasowych wielokrotnie problematyzowała kwestię wykorzystywania w reportażach wiedzy o rozmówcach czy wręcz rezygnacji z zadawania pewnych pytan ${ }^{73}$. W jednym $\mathrm{z}$ artykułów (z początku lat osiemdziesiątych) przyznała:

Zmienia się z wiekiem mój pogląd na to, co wolno. Im jestem starsza, tym łagodniejsza. Kiedyśs uważałam, że szyfrując bohatera wolno sporo. Dziś myślę, że coraz mniej. Za każdym razem reporter musi sam rozstrzygnąć, jak blisko wolno mu podejść do bohatera i jak bardzo odsłonić go ${ }^{74}$.

Czy w przypadku opowieści o losach Izoldy R. reporterka przekroczyła granice intymności i dobrego smaku? Czy „zdradziła” bohaterkę? Warto przywołać tu raz jeszcze laudację Kapuścińskiego, w której zwraca on uwagę na istotny aspekt twórczości Krall:

Postacie, z jakimi stykamy się w jej książkach, występują [...] w potrójnej roli - jako świadkowie zagłady, jako przewodnicy do zaginionego świata i jako bohaterowie literaccy. Ta trójjedność owych ról umacnia i uwyraźnia ich sylwetki ${ }^{75}$.

Izolda jako świadek Zagłady - opowiada o swoich przeżyciach. Według reporterki spełnia w ten sposób obowiazek moralny. Druga $z$ ról wymienionych przez Kapuścińskiego wiąże się z koniecznością uzupełnienia relacji o możliwie wiele szczegółów. Reporterka, pragnąc wiernie opisać rzeczywistość zapamiętaną przez swoją rozmówczynię, ,zadaje pytania. Dziesiątki, setki pytań. Przecież wszystko jest ważne!"76 Chcąc uwypuklić te autentyczne detale, w książce Król kier znów na

Zob. np. utrzymany w napastliwym tonie artykuł opublikowany w „Zwierciadle”, przytaczany przez Meloch (op. cit.).

Kon e cka, op. cit.

Taką sytuację Krall opisuje w rozmowie z T. S o b olew s ki m Scalanie świata („Gazeta Wyborcza” 2000, nr z 17 XI) czy w rozmowie z J a nowską i Mucharskim (op. cit.)

Meloch, op. cit. Kilkanaście lat później Krall stwierdzi w wywiadzie (Bielas, op. cit., s. 22): „Muszę przenikać kolejne bariery intymności, ale zdecydowanie nie chcę zadawać cierpień”.

Ka puścińs ki, op. cit., s. 16.

Ibidem. 
wylocie $^{77}$ posuwa się nawet do tego, by - wbrew woli bohaterki - w jej ubiorze „skrócić” palto:

Miała na sobie otrzymane w prezencie pończochy z ciemną strzałką powyżej kostki. Ta strzałka była bardzo ważna, bo modna, „najmodniejsza w sezonie”. Bo był świat, w którym była jakaś moda i w którym były modne pończochy ze strzałką powyżej kostki.

I te pończochy musiały być widoczne spod palta ${ }^{78}$.

Mimo usilnych nalegań Izoldy („Znowu nie mogła spać przez cała noc: „Pani Haniu, jak ja będę wyglądała w takim kusym palcie?" "79) reporterka do tego opisu zmian nie wprowadza. Paradoksalnie, przedstawienie „zaginionego świata” jest dla Krall istotniejsze niż brak akceptacji wobec powstałego tekstu (co warto raz jeszcze podkreślić: motywowany estetycznie) ze strony przewodniczki po tym świecie ${ }^{80}$. Jeśli chodzi zaś o Izoldę jako bohaterkę literacką, to można się zastanowić, czy zdołałaby ona rozpoznać się w napisanym zgodnie $z$ jej oczekiwaniami schematycznym (kiczowatym) romansie, pozbawionym wzmianek o jej pokorze wobec męża? Czy taki wizerunek nie podważyłby, w konsekwencji, trójjedności ról postaci, które wymieniał Kapuściński? Czy nie okazałby się po prostu niestosowny - również względem samej ocalonej?

W zakończeniu Powieści dla Hollywoodu reporterka przekazuje maszynopis z historią ocalonej - „doświadczonej redaktorce Wydawnictwa Literackiego” (H 35-36). Książka, zatytułowana Wygrana wojna Izoldy R., znalazła jej aprobatę: „Mam tylko jedną uwagę - dodała. - Kompozycyjną. Czy ten mąż nie powinien jej znacznie wcześniej porzucić? Dla powieści tak byłoby naprawdę lepiej” (H 36). Reakcja redaktorki (która najwyraźniej uznała tekst za fikcjonalny), podobnie jak wspomniane już, pełne ironii spostrzeżenia reporterki-narratorki, świadczą o zdawaniu sobie sprawy z przemożnego wpływu, jaki na kształt opowieści o Zagładzie mogą mieć odbiorcy. Wszak spełnienie ich oczekiwań najpewniej przyniosłoby książce powodzenie na rynku wydawniczym. Dla Krall jednak najważniejsza pozostaje sama opowieść. Bierze ją bowiem w obronę: przed tymi czytelnikami, dla których historie muszą być w pierwszej kolejności - atrakcyjne; przed samą sobą i nadmiernym reporterskim zafascynowaniem zdarzeniami; oraz, choć nie bez dylematów moralnych, przed bohaterami reportażu:

Los bohatera jest straszny, zwłaszcza autentycznego bohatera - a ja tylko o takich piszę. Bohater musi się pogodzić $\mathrm{z}$ wizją, $\mathrm{z}$ wyobrażeniem autora. A w dodatku autor mówi mu, że tak będzie dla niego najlepiej. Może nie całkiem dla niego. Dla książki lepiej, a to jest przecież najważniejsze ${ }^{81}$.

Na temat związków tej książki z reportażem Powieść dla Hollywoodu i o pozostałych wersjach tekstów o losach Izoldy zob. cytowany już artykuł: J 40-41.

Kę c zkowska, op. cit., s. 9.

Ibidem.

Zob. M. Kisie1, Los jako pamięć. „Wiadomości Kulturalne” 1994, nr 20, z 9 X: „Krall jest [...] nieufna wobec swoich rozmówców i jakkolwiek umie pięknie opowiedzieć ich dzieje, postępuje jak rasowy realista. Tam gdzie trzeba - podaje nawet bibliografię opracowań historycznych. I dopiero wtedy rozumiemy, na czym polega siła jej warsztatu pisarskiego. A jest nią dążenie do prawdy, nawet jeśli byłaby ona odmienna od tej, którą przekazuje bohater reportażu”.

Sobolews ka, op. cit., s. 22. 
Abstract

ANNA TATAR University of Warsaw

TOWARDS THE SALVAGED AND THEIR STORIES ELEMENTS OF HANNA KRALL'S REPORTER FIELD OF ACTIVITY

The article takes into consideration referring to the connections of two fundamental features of creativity of Hanna Krall, a reporter, who narrates about the Shoah, as the connection proves vital to attempts at characterising her field of activity and at understanding literary output. Both a report (broadly understood as a literary genre, writing method and even realisation of ethical stance) and the theme of extermination impose on her certain requirements and limitations. Not only being a match for them, but first and foremost transgressing them for great literature determines the specificity of her creativity. Looking at the problems, the author of the article strives to analyse and interpret the text Powieść dla Hollywoodu (A Tale for Hollywood) from the collection Hipnoza (Hypnosis). Included in it reflection over her own field of activity allows to regard the report as a peculiar kind of programmatic manifesto formulated in the initial phase of her writing about the fortune of the Jewish people. 